\title{
Future Electricity Market Structure to Ensure Large Volume of RES
}

\author{
Artjoms Obushevs, Irina Oleinikova \\ Smart Grid Research Centre \\ Institute of Physical Energetics \\ Riga, Latvia
}

A.Obusev@gmail.com, Irina.Oleinikova@edi.lv

\begin{abstract}
The article define set of rules for future Electricity market structure, taking into account network codes, legislation and directives to ensure RES integration targets and Energy Union Dimensions in term of a fully integrated internal energy market and transition to a long lasting low-carbon society. Presented research studies are based on new way of power system operation development, namely Web-of-cell concept, of FP7 IRP ELECTRA. It's aiming to ensure conceptual E-market design and future power system $2030+$ control solutions.
\end{abstract}

Index Terms-- Electricity Market, Renewable Energy, Ancillary Services.

\section{INTRODUCTION}

Significant amounts of variable renewable capacity have been installed already and a lot more will be deployed by 2020 and beyond. The increase in numbers causes significant changes in power system operation manner. With one of the main objectives of the EU being decarbonizing the energy sector, by having increasing amounts of Renewable Energy Sources (RES), a reliable system operation requires increasing balancing capabilities in electric power systems [1].

In the $2030+$ power system, it is expected that generation will shift from mostly few large central generators to many smaller distributed generators. The local fluctuations will increase the activation of reserves. Flexible operation of the networks requires radically new control schemes, which enable grid operators to ensure dynamic balance and stability in a future power system with a high share of decentralized generation.

As an increasing share of intermittent generation as well as an increasing share of flexible loads will be connected to the distribution grid that is increasingly heavy (peak) loaded, it is likely that Distribution System Operators will assume an increasingly important role in keeping the system stable.

Variable renewable energy sources can affect the design of ancillary services markets in the following ways: the variability and uncertainty of wind and solar energy increases

\author{
Mazheruddin Syed, Ammar Zaher and Graeme Burt \\ Institute for Energy and Environment \\ Dept. of Electronics and Electrical Engineering \\ University of Strathclyde, Glasgow, Scotland
}

requirements for various ancillary services, affecting the scheduling and pricing of those services. Their impacts vary depending on system condition, which makes the ancillary service demands difficult to be generalized across timescales and systems [2]. Allowing variable renewable energy and demand to participate in the ancillary service markets can offer more supply to the market, but could offer challenges based on the unique characteristics of variable resources. The different type of flexibility resources connected at the different power grid levels, and their characteristics can affect power system operation and market mechanisms implementation. The interactions between the different stakeholders become more complex in an increasingly flexible power system (presented in fig.1 and fig.2).

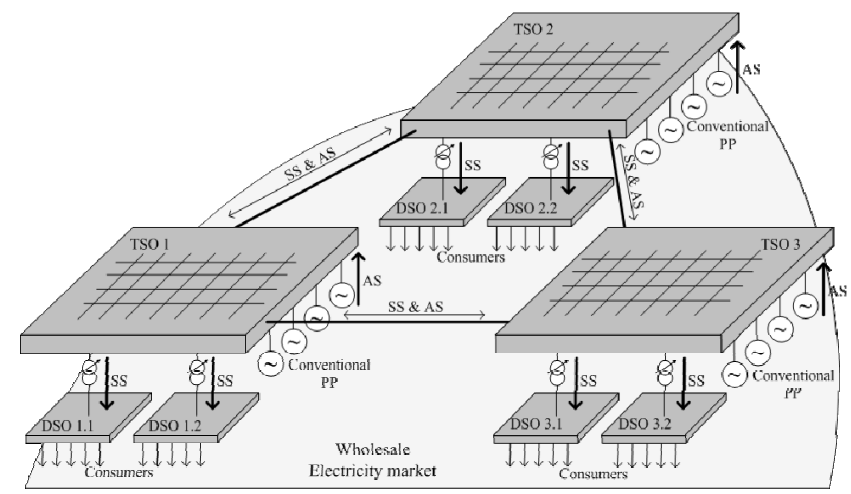

Figure 1. Traditional Power system representation

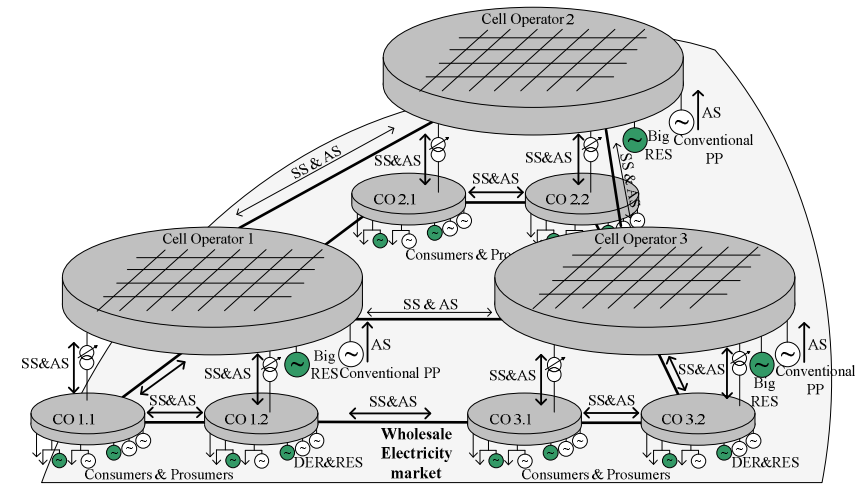

Figure 2. 2030+ Power system representation in scope of ELECTRA project $[3,4]$ 
As we are in a fundamental transformation of the electricity system by integrating high share of RES, which is driven by new Renewables Directive post-2020, ensuring a timely and cost effective achievement of the at least 27\% EUlevel binding RES targets. Therefore enhanced the market design is needed to facilitate EU-wide member state centric approach to renewable deployment, where the following challenges to new electricity market design are underlined:

- Making the market work effectively -wholesale and retail;

- A coordinated approach to Capacity Remuneration;

- Stepping up regional cooperation;

- Ensuring coordination and cooperation in times of crisis;

- Adapting the institutional framework.

From the Regional cooperation perspectives it is important to mention the large gains are available if there is a true common market for renewable energy as envisaged by the EU Renewables Directive. This will be achieved by making it commercially desirable to locate renewable generation capacity in locations that are most effective for it, which will be a key for supporting cost efficient evolution to lower carbon EU energy system.

At present there exists no long-term market for such cross border capacity, for example, which has put a severe commercial risk on EU development of EU wide long-term renewable energy projects. Energy markets, renewables markets, and capacity markets need to be truly international if cost savings are to be achieved while maintaining security of supply, deploying renewables and to empower consumers to deploy cost-optimal renewable energy solutions.

\section{INTEGRATING RENEWABLE GENERATION}

To explore and assess the innovative market design with related policy and regulations, such as the "Third Legislative Package" improved competition and consumers' protection (Directive 2009/72/EC), set up of the Agency for the Cooperation of the Energy Regulators (Regulation 713/2009/EC) and the European Network for Transmission System Operators (Regulation 714/2009/EC) were analyzed, taking into account the importance of the RES evaluation and development in the recent years as regards the electricity market and power system operation as a whole.

Today, various market participants (electricity producers, consumers and electricity suppliers, investors, distribution and transmission network operators etc.) operate at different market levels (retail or wholesale) within various sub-markets (day-ahead, intraday, balancing, ancillary services presented in fig.3) and trade different products (hourly contracts, peak load, off-peak load etc.). The combination of different electricity sub-markets and direct control mechanisms, the frequency and voltage control services must be obtained to ensure the security of supply in all power system operational levels.

\section{Energy Markets}

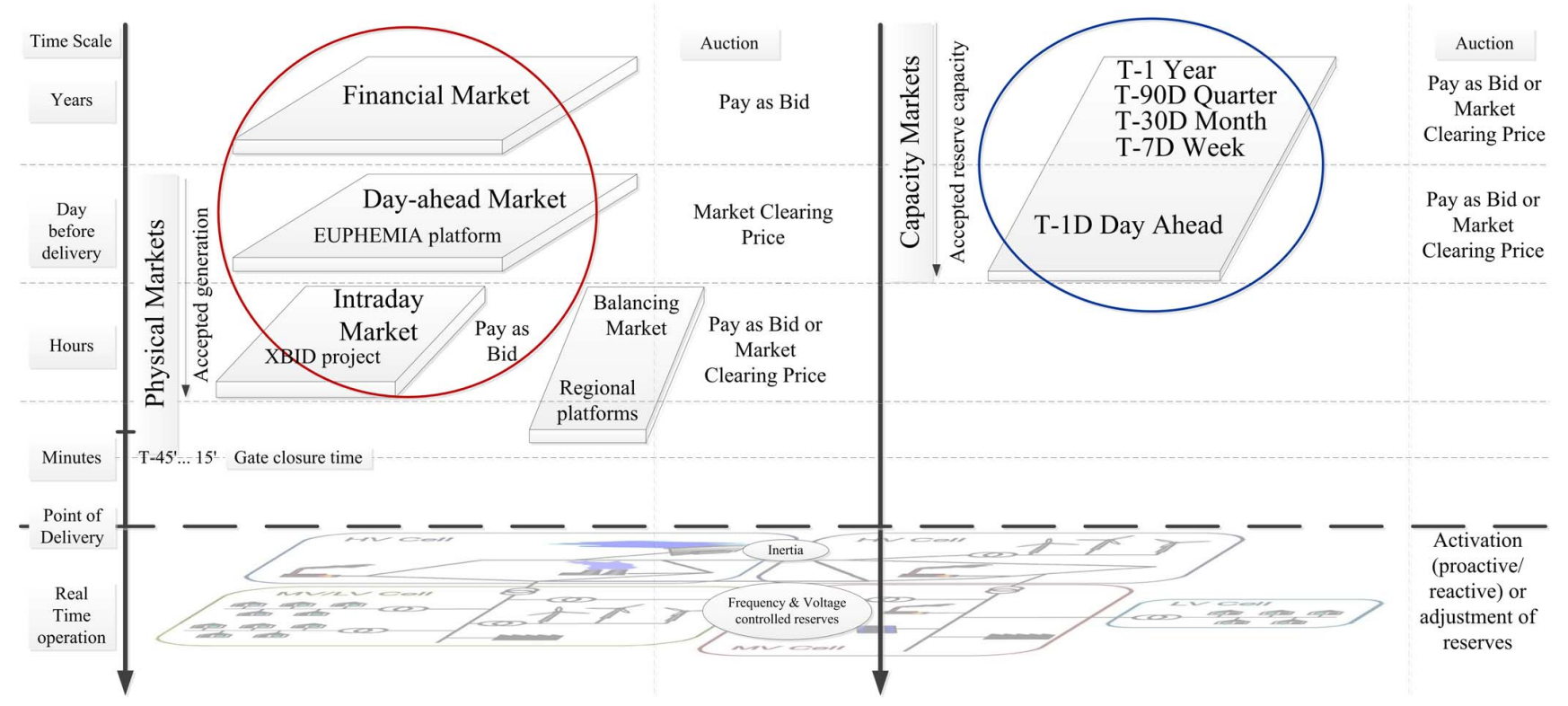

Figure 3. Current Electricity Market Design

\section{Current Electricity Market Design Capacity Markets}

FCR/FRR/RR/Primary/Secondary/Tertiary voltage control
Cigure 3. Current Electricity Market Design
Due to the major changes mentioned before, the essential feature of electricity market design will be focused on the System Services (SS), provided by TSOs and Ancillary Services (AS), in their turn - provided to the system operator by generators and consumers. The classification of ancillary services is given in Table I. [5] 
TABLE I. ANCILLARY SERVICES

\begin{tabular}{|c|c|c|c|c|}
\hline $\begin{array}{l}\text { Active/ } \\
\text { reactive }\end{array}$ & Status for reserves & $\begin{array}{c}\text { Reserve } \\
\text { readiness }\end{array}$ & Control & Provider \\
\hline $\begin{array}{l}\text { Active } \\
\text { Power }\end{array}$ & $\begin{array}{l}\text { In stand-by mode } \\
\text { (ready to be activated) }\end{array}$ & $\begin{array}{l}\text { Spinning } \\
\text { Hot stand- }\end{array}$ & Automatic & $\begin{array}{l}\text { Supply } \\
\text { side }\end{array}$ \\
\hline $\begin{array}{l}\text { Reactive } \\
\text { Power }\end{array}$ & $\begin{array}{l}\text { In activated mode } \\
\text { (called up and } \\
\text { participating) }\end{array}$ & $\begin{array}{l}\text { by } \\
\text { Cold } \\
\text { stand-by }\end{array}$ & Manual & $\begin{array}{l}\text { Demand } \\
\text { side }\end{array}$ \\
\hline
\end{tabular}

In practice ancillary services fundamentals are defined by the relevant TSO [5-8]. This choice should correspond to system characteristics, including needs of the synchronous area/ protection plan and also the capability of the generating technology; they usually include: ancillary services requirements / Interdependencies / Coordination between TSO-DSO-Grid User. The characteristics of the EU Electricity Markets for Frequency control ancillary services in term of Procurement procedure and Remuneration Scheme is given in Table II.

TABLE II. CHARACTERISTICS OF THE MARKETS FOR FREQUENCY CONTROL ANCILLARY SERVICES

\begin{tabular}{|c|c|c|c|c|c|c|}
\hline \multirow[b]{2}{*}{ Country } & \multicolumn{2}{|c|}{ Frequency Containment Reserve } & \multicolumn{2}{|c|}{ Frequency Restoration Reserve } & \multicolumn{2}{|c|}{ Replacement Reserve } \\
\hline & $\begin{array}{l}\text { Procurement } \\
\text { Scheme }\end{array}$ & Remuneration & $\begin{array}{l}\text { Procurement } \\
\text { Scheme }\end{array}$ & Remuneration Scheme & $\begin{array}{l}\text { Procurement } \\
\text { Scheme }\end{array}$ & Remuneration Scheme \\
\hline Finland & Voluntary market & Yes & Market based & $\begin{array}{l}\text { Marginal pricing/Annual } \\
\text { Contract }\end{array}$ & No Market based & Mandatory requirement \\
\hline Italy & $\begin{array}{l}\text { Mandatory } \\
\text { provision }\end{array}$ & No & Market based & Pay as bid & Market Based & Pay as bid \\
\hline Norway & Organized market & Yes & Market based & $\begin{array}{c}\text { Marginal pricing/Pay as } \\
\text { bid }\end{array}$ & Market based & Marginal Pricing \\
\hline Poland & $\begin{array}{l}\text { Mandatory } \\
\text { /Contract }\end{array}$ & Yes & $\begin{array}{c}\text { Mandatory } \\
\text { /Contract/Market } \\
\text { based }\end{array}$ & Marginal price/Contracts & Mandatory & $\mathrm{n} / \mathrm{a}$ \\
\hline Portugal & $\begin{array}{l}\text { Mandatory } \\
\text { provision }\end{array}$ & No & $\begin{array}{l}\text { Mandatory } \\
\text { /contract }\end{array}$ & $\mathrm{n} / \mathrm{a}$ & No market based & $\mathrm{n} / \mathrm{a}$ \\
\hline Spain & $\begin{array}{l}\text { Mandatory } \\
\text { provision }\end{array}$ & No & Market based & Pay as bid & Market Based & Marginal pricing \\
\hline Turkey & $\begin{array}{l}\text { Mandatory } \\
\text { provision }\end{array}$ & Yes & Market Based & $\begin{array}{c}\text { Pay as bid/Opportunity } \\
\text { cost }\end{array}$ & Market Based & Pay as bid \\
\hline France & $\begin{array}{l}\text { Mandatory } \\
\text { provision }\end{array}$ & Yes & Contract & Pay as bid & $\mathrm{n} / \mathrm{a}$ & $\mathrm{n} / \mathrm{a}$ \\
\hline Germany & $\begin{array}{l}\text { Mandatory } \\
\text { provision }\end{array}$ & Yes & Market based & Pay as bid & Market based & Pay as bid \\
\hline $\begin{array}{c}\text { Great } \\
\text { Britain }\end{array}$ & $\begin{array}{l}\text { Mandatory } \\
\text { provision }\end{array}$ & Yes & Market based & Pay as bid & Market based & $\begin{array}{c}\text { Marginal pricing/Pay as } \\
\text { bid }\end{array}$ \\
\hline Sweden & $\begin{array}{l}\text { Mandatory } \\
\text { provision }\end{array}$ & Yes & Market based & Pay as bid & Annual Contract & Pay as bid \\
\hline
\end{tabular}

\section{ENSURING FLEXIBILITY}

RES development technologies are taking number one leadership, by developing highly performant renewables technologies and their integration in the power system. As well as consumers are placed at the centre of the future energy system. Therefore the resilience, security and smartness of the energy system came to front from the technical, organizational, and economic point of view including coordination and integration.

Taking into account all mentioned before the General requirements for system transition are listed in the Table III.

TABLE III. GENERAL REQUIREMENTS FOR SYSTEM TRANSITION

\begin{tabular}{|c|c|}
\hline STATEMENT & ACTION \\
\hline $\begin{array}{l}\text { Grid Observability and } \\
\text { controllability }\end{array}$ & $\begin{array}{c}\text { Technology enable to remotely monitor and } \\
\text { control more than } 80 \% \text { of HV-MV } \\
\text { substations and } 25 \% \text { at LV }\end{array}$ \\
\hline Variability and uncertainty & $\begin{array}{l}\text { Should enable peak load to be reduced by } \\
25 \% \text { due to demand response by } 2030\end{array}$ \\
\hline $\begin{array}{l}\text { Increased grid hosting } \\
\text { capacity }\end{array}$ & By monitoring only \\
\hline $\begin{array}{c}\text { Flexibility and } \\
\text { decentralization of the } \\
\text { thermal power generation }\end{array}$ & $\begin{array}{l}50 \% \text { of the thermal power plans by } 2030 . \\
\text {-doubling of average ramping-rates } \\
\text {-having efficiency losses for part-load } \\
\text {-reducing minimum load by } 30 \%\end{array}$ \\
\hline
\end{tabular}

The need for a transition towards a new architecture is based on a number of assumptions regarding the 2030+ power system. The EU power grid is decomposed into a Web-OfCells structure. Each control cell has adequate monitoring infrastructure installed, as well as local reserves capacity enabling them to (partially) resolve voltage and control cell balancing problems locally. Each control cell is managed by a single system operator, who takes responsibility for the realtime reserves activation and dispatching in his cell. Inter-cell reserve exchanges and coordination is included for optimal system-wide management. In each control cell, the control cell operator maintains an accurate view on the overall cell state, and dispatches reserves located in the cell in a secure manner based on his knowledge of the cell state. In the proposed Webof-Cell based architecture, control cell operators are responsible to contribute to containing and restoring system frequency, as well as containing local voltage within secure and stable limits. In comparison to state of the art power system control the Inertia Response Power Control is introduced. This control assures that sufficient units (also inverter-coupled) contribute to the limitation of ROCOF. For this, system inertia is required as a new observable to select the contributing units depending on the system state. The main 
further development for Frequency containment control is to increase flexibility by usage of multiple kinds of units depending on their technological strengths. Frequency Restoration and Replacement is replaced by Balance Restoration and Balance Steering Control, in which the main objective is the restoration of balance within each Control
Cell. The main further development for PVC is the usage of multiple kinds of units for stabilizing grid voltage. PostPrimary Voltage Control replaces secondary and tertiary voltage control, the goal is to solve voltage issues as local as possible [10]. Overview of the control schemes transition is listed in the Table IV.

TABLE IV. SUMMARY/OVERVIEW OF THE CONTROL SCHEMES (ANCILLARY SERVICES) FOR CURRENT AND FUTURE ARCHITECTURE [9-11]

\begin{tabular}{|c|c|}
\hline $\begin{array}{c}\text { Now } \\
\text { Centralised architecture } \\
\end{array}$ & $\begin{array}{c}\text { Future } \\
\text { Decentralised web-of-cell architecture }\end{array}$ \\
\hline \multicolumn{2}{|c|}{ Frequency control } \\
\hline & $\begin{array}{l}\text { Inertia Response Power Control (IRPC), where each unit, involved in } \\
\text { inertia control, automatically changes its level of inertia power response } \\
\text { (synthetic inertia) depending on certain predefined characteristics. - Reacts } \\
\text { to frequency changes over time }\end{array}$ \\
\hline $\begin{array}{l}\text { Frequency Containment Reserves (FCR) are used for the constant } \\
\text { control of frequency } \\
\text { Control uses new resources as frequency-controlled demand from } \\
\text { distributed loads and distributed control/MicroGrids }\end{array}$ & $\begin{array}{l}\text { Frequency Containment Control (FCC) will not be fundamentally } \\
\text { changed compared to today's schemes, except that the resources providing } \\
\text { containment reserves will be different: generating units (in the broadest } \\
\text { sense) as well as loads and storage distributed across the power grid (within } \\
\text { each cell). - Reacts to deviations of the absolute frequency value so as to } \\
\text { contain any change and stabilise frequency to a steady-state value }\end{array}$ \\
\hline $\begin{array}{l}\text { Frequency Restoration Reserves (FRR) are used to return the } \\
\text { frequency to its normal range and to release activated FCR back into } \\
\text { use } \\
\text { Control includes an increased involvement of Non-programmable } \\
\text { RES with centralized and local dispatching. The latter entails DSO to } \\
\text { be responsible for the services towards TSO, participating in the } \\
\text { ancillary service market }\end{array}$ & $\begin{array}{l}\text { Balance Restoration Control (BRC) initiates the restoration of the cell } \\
\text { balance and load flows based on local information. It is assumed that } \\
\text { (almost) all prosumers, that are connected through public communication } \\
\text { infrastructure, will be able to offer fast BRC capacity, e.g. through their } \\
\text { flexible loads, and possibly local storage. - Reacts to absolute frequency } \\
\text { deviations in conjunction with the tie line deviations from the scheduled } \\
\text { interchanges so as to restore both quantities to their initial values }\end{array}$ \\
\hline $\begin{array}{l}\text { Replacement Reserves (RR) are used to restore the required level of } \\
\text { operating reserves in the categories of FCR and FRR reserves due to } \\
\text { their earlier usage } \\
\text { Control includes a number of potential resources at both transmission } \\
\text { and distribution levels: consumers at LV distribution level, } \\
\text { Distributed Generators as wind and PV, centralised storage as } \\
\text { pumped hydro and distributed storage as EVs. }\end{array}$ & $\begin{array}{l}\text { Balance Steering Control (BSC) will replace the BRC in a more } \\
\text { economic manner if this can be done safely or adjust the balance set points. } \\
\text { It can as well have pro-active activation based on prognoses. This control } \\
\text { deploys resources not only within the cell but also from neighbouring cells. } \\
\text { - Regulates power balance within a Cell in order to replace BRC reserves } \\
\text { or mitigate potential imbalances in a cost effective manner }\end{array}$ \\
\hline \multicolumn{2}{|c|}{ Voltage control } \\
\hline $\begin{array}{l}\text { Primary Voltage control is a process that is performed locally by } \\
\text { each network element which has voltage control capability. The } \\
\text { future schemes in addition to the conventional power plants are } \\
\text { expected to include RES and Microgrids. }\end{array}$ & $\begin{array}{l}\text { Primary Voltage control is not expected to have fundamental changes } \\
\text { compared to today's primary voltage control, except that the resources used } \\
\text { will be different: generating units (in the broadest sense) as well as loads, } \\
\text { storage devices and FACTS. These resources will be procured within every } \\
\text { cell, and will thus be distributed over different voltage levels. - Reacts in } \\
\text { case of voltage deviations measured in the nodes of the cells as a } \\
\text { consequence of a severe disturbance }\end{array}$ \\
\hline $\begin{array}{l}\text { The secondary voltage control in future grids can cover both the } \\
\text { regional control within a certain zone of the TSO's control area and } \\
\text { the voltage control at the distribution system level. The secondary } \\
\text { voltage and reactive power control at the transmission grid controls } \\
\text { the reactive power at certain pilot-nodes in the transmission grid. } \\
\text { Each pilot-node is representative for the voltage within a certain zone. } \\
\text { The secondary controller changes the reactive power provided by the } \\
\text { devices (power plants or reactive power equipment of the TSO (e.g. } \\
\text { capacitors banks) or reactive Power provided by distribution grids) } \\
\text { within this zone until the voltage at the pilot-node is at the desired } \\
\text { level. The secondary voltage and reactive power control of the } \\
\text { distribution grid controls the reactive power at certain pilot-nodes in } \\
\text { the medium voltage network of the distribution grid. The reactive } \\
\text { power requested by the DSO can be provided by one or more } \\
\text { aggregators which send the reactive power request to their devices } \\
\text { which are present in the zone of a certain MV pilot-node or can be } \\
\text { directly controlled by the DSO himself. } \\
\text { Tertiary voltage control is a process that acts on a system wide scale } \\
\text { and in a time range of about } 10 \text { to } 30 \text { minutes. The objective of } \\
\text { tertiary voltage is to optimize the operation of the network by } \\
\text { maintaining the required voltage quality and the substitution of } \\
\text { reactive reserves. }\end{array}$ & $\begin{array}{l}\text { Post-Primary Voltage control (PPVC) has the commitment to bring the } \\
\text { voltage levels in the nodes of the power system back to nominal values } \\
\text { while optimizing the reactive (and active) power flows in order to reduce } \\
\text { the losses in the network. } \\
\text { Each cell is responsible for its own voltage control while a close } \\
\text { coordination between neighboring cells guarantees the provision of PPVC } \\
\text { service between neighboring cells. }\end{array}$ \\
\hline
\end{tabular}




\section{WOC MARKET DESIGNS - ENERGY\&CAPACITY}

Currently, both day-ahead and intra-day markets are performed based on separated forecasts of energy needs, system congestions, and system contingencies, among others. Obviously, a better approach would be to perform all these forecasts in an integrated and unified manner by web-of-cell concept. Potential changes to the existing ancillary services markets are likely to occur due to the changing requirements of those ancillary services which should be carefully considered to eliminate any unintended consequences [12]. The Market Design rules guiding the ancillary services markets should not preclude technologies that can provide the desired need and this may soon include ancillary services being provided by flexibility sources.

Web-of-Cell methodology [13] would allow network/cell operators to achieve an optimal reliability and decisionmaking under uncertain dynamic conditions. The fig. 4 is aiming to demonstrate vision to overall electricity market design with web-of-cell concept and expected auction mechanisms. Overview of the frequency control ancillary services is listed in the Table $\mathrm{V}$.

Electricity market design with web-of-cell concept

\section{Energy Markets}

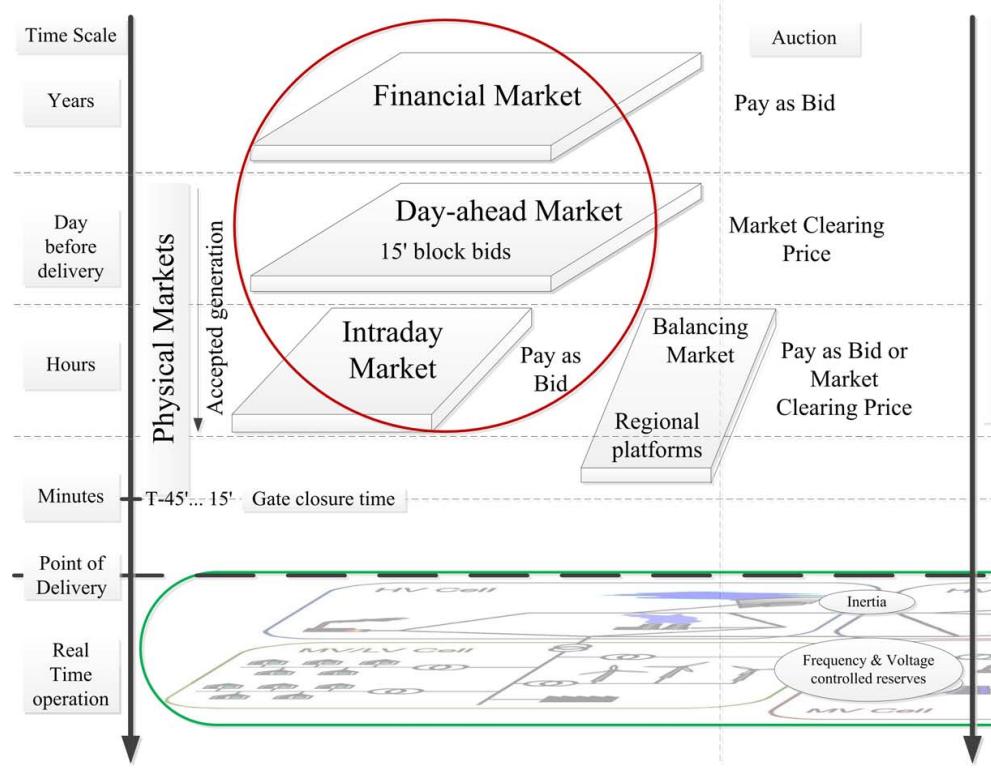

Capacity Markets IRPC/FCC/BRC/BSC/PVC/PPVC

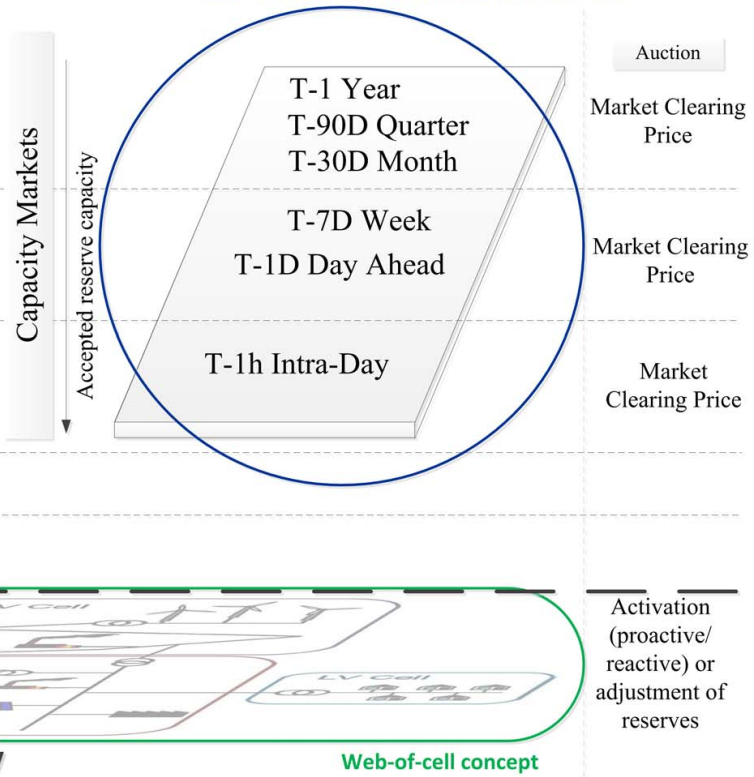

Figure 4. Electricity market design with WoC concept

TABLE V. FREQUENCY CONTROL ANCILLARY SERVICES

\begin{tabular}{|c|c|c|c|}
\hline $\begin{array}{c}\text { Frequency } \\
\text { control }\end{array}$ & Objective & Resources & Product definition \\
\hline IRPC & $\begin{array}{l}\text { Service from cell to minimize frequency drop/fluctuations } \\
\text { O1: distribute the cell's received inertia setpoint over a number of inertia providing } \\
\text { resources taking into account the forecasted cell's state so that inertia activations do } \\
\text { not cause grid problems. } \\
\text { O2: optimal selection of inertia providing resources to maximize the containment of } \\
\text { local deviations or incidents (and minimize frequency deviation } \Delta \text { f that would be } \\
\text { observed by distant cells) }\end{array}$ & $\begin{array}{l}\text { Rotating energy (generation, motors) } \\
\text { and artificial inertia (storage, } \\
\text { converters) }\end{array}$ & $\begin{array}{l}\text { Activation triggered by } \Delta \mathrm{f} / \Delta \mathrm{t} \text { restriction. The } \\
\text { product could be based on the dynamic } \\
\text { characteristics related to its dynamic } \\
\text { generation mix and/or the expected deviations } \\
\text { from set points that would cause imbalances } \\
\text { and set point deviations. }\end{array}$ \\
\hline $\mathrm{FCC}$ & $\begin{array}{l}\text { Identification and regulation of a characteristic steady state response to the } \\
\text { Synchronous frequency deviation. } \\
\text { O1: Decomposition of the cell's received cell power frequency characteristic into } \\
\Delta \mathrm{P} / \Delta \mathrm{f} \text { droop settings of available FCC resources taking into account the cell's } \\
\text { forecasted grid state so that FCC activations do not cause grid problems } \\
\text { O2: Contain dynamic and steady-state frequency deviations (at the same timescale } \\
\text { as BRC) } \\
\text { O3: Activation of FCC reserves mainly within cells causing the deviation (and } \\
\text { minimizing activations in balanced cells) } \\
\text { O4: Reduce the overall use of FCC reserves all over the synchronous area }\end{array}$ & $\begin{array}{l}\text { Hydro/thermal generation and inverter- } \\
\text { based DER (RES, Storage, DGs and } \\
\text { loads), which provide a substantial } \\
\text { granularity in terms of cell power } \\
\text { frequency characteristic optimal } \\
\text { configuration and are capable of } \\
\text { adapting much faster to changes } \\
\text { imposed by the control by contrast } \\
\text { with the slow synchronous generators }\end{array}$ & $\begin{array}{l}\text { Automatically triggered between } \\
49,9-50,1 \mathrm{~Hz} \text {. } \\
\text { Response requirement: "instantaneous" } \\
0-50 \% \text { within } 15 \mathrm{sec}, 50-100 \% \text { within } 30 \mathrm{sec}\end{array}$ \\
\hline BRC & $\begin{array}{l}\text { Restoring cell balance according to planned power exchange } \\
\text { "Using traditional ACE control algorithms" } \\
\text { O1: Maintain the cell balance (sum of cell tie-line import/export powerflows) in line } \\
\text { with the received setpoint } \\
\text { O2: Restore frequency next to balance. } \\
\text { In the ELECTRA Web-of-Cells concept the BRC runs at the same timescale as FCC } \\
\text { and therefore contributes to frequency containment as well as balance/frequency } \\
\text { restoration. }\end{array}$ & $\begin{array}{l}\text { Generation, } \\
\text { available DER - controllable devices }\end{array}$ & $\begin{array}{l}15 \mathrm{~min} \text { time resolution. } \\
\text { Response requirement: Activation }<30 \mathrm{sec} \text {, } \\
\text { reach required capacity within } 15 \mathrm{~min}\end{array}$ \\
\hline $\mathrm{BSC}$ & $\begin{array}{l}\text { Supervisory control actions involving "adjoining" cells } \\
\text { O1: Minimisation and/or optimisation of activated balancing reserves (active power } \\
\text { (de)activations) } \\
\text { O2:Not violating tie-line power flow constraints }\end{array}$ & $\begin{array}{l}\text { Generation, } \\
\text { available DER - controllable devices }\end{array}$ & $\begin{array}{l}15 \text { min time resolution. } \\
\text { Response requirement: Activation }<30 \mathrm{sec} \text {, } \\
\text { reach required capacity within } 15 \mathrm{~min} \\
\text { Minimum duration: } 2 \mathrm{~h}\end{array}$ \\
\hline
\end{tabular}




\section{CONCLUSIONS}

The current EU electricity market contains several bidding zones, usually based on historical context and geo-political factors corresponding to a member state. The new role of the system operators and of the new actors is to guarantee the quality and security of supply at minimal costs within the market framework in force. This function contains specific requirements for all the EU synchronous system with a particular focus on the future market design for electricity, taking into account the current structural changes.

In the future power system scheme, TSOs will be able to control significantly lower part of the generation compared to the traditional centralized configuration, and thus they will not be able any more to compensate large deviations in the power balance, therefore the concept of web-of-cell were presented. Even theoretically a large power imbalance could be faced with accurate day-ahead predictions of decentralized generation and electricity demand of load centers, in practice this will be very difficult due to the intermittent distributed generation profile. Moreover, increased electricity loads and sources such as EVs and residential PV systems, will influence the balance between day-ahead production and consumption schedule and will leave energy markets with higher and less predictable need for balancing power.

\section{ACKNOWLEDGMENT}

The work in this paper has been supported by the European Commission, under the ELECTRA REX researcher exchange programme of the FP7 project ELECTRA (grant no: 609687; web site www.ElectraIRP.eu).

\section{REFERENCES}

[1] M. Rautkivi, M. Kruisdijk, "Future Market Design for Reliable Electricity Systems in Europe," present. at the POWERGEN Europe'13

[2] A. Obushevs, I. Oleinikova. Market Design for Electricity Ensuring Operational Flexibility // 5th International Conference on Power Engineering, Energy and Electrical Drives (PowerEng'2015) Riga, Latvia, 11-13 May 2015

[3] ELECTRA IRP: European liaison on electricity committed towards long-term research activity integrated research programme. [Online]. Available: http://www.electrairp.eu/

[4] L. Martini, L. Radaelli, H. Brunner, C. Caerts, A. Morch, S. Hanninen, C. Tornelli, 2015, "ELECTRA IRP approach to voltage and frequency control for future power systems with high DER penetrations ", CIRED 2015 conference, AIM, vol.1, 210-220

[5] I. Wangensteen, Power System Economics - the Nordic Electricity Market, Tapir Akademisk Press, Trondheim, 2012. ISBN 978-82-5192863-2.

[6] Y. G. Rebours, D. S. Kirschen, M. Trotignon, and S. Rossignol, “A survey of frequency and voltage control ancillary services-Part I: Technical features," IEEE Transactions on Power Systems. , vol. 22, no. 1, pp. 350-357, Feb. 2007

[7] Y. G. Rebours, D. S. Kirschen, M. Trotignon, and S. Rossignol, "A survey of frequency and voltage control ancillary Services-Part II: Economic Features," IEEE Transactions on Power Systems, vol. 22, p. 358-366, feb 2007

[8] E. Rivero, J. Barquín, and L. Rouco, "European balancing markets," presented at the 8th International Conference on the European Energy Market, Zagreb, Croatia, 2011, pp. 333-338.

[9] R. D’hulst, J. M. Fernandez, E. Rikos, D. Kolodziej, K. Heussen, D. et al. "Voltage and frequency control for future power systems: the
ELECTRA IRP proposal," in Proc. Int. Symp. on Smart Electric Distribution Systems and Technologies (EDST), Vienna: IEEE, 2015.

[10] A: Morch et al. 2015, "Adaptive Assessment of Future Scenarios and Mapping of Observability Needs" ELECTRA Deliverable D5.1. WP5: Increased Observability. Available for download at http://www.electrairp.eu/

[11] A. Z. Morch, S. H. Jakobsen, K. Visscher, M. Marinelli, "Future control architecture and emerging observability needs," in Power Engineering, Energy and Electrical Drives (PowerEng'2015), Riga, Latvia, 11-13 May 2015

[12] E.Ela, B.Kirby, N.Navid, J.C.Smith, "Effective ancillary services market designs on high wind power penetration systems," in Proc. 2012 IEEE PES General Meeting, San Diego, USA, Jul. 2012

[13] C Caerts et al. 2015 "Specification of Smart Grids high level functional architecture for frequency and voltage control" ELECTRA Deliverable D3.1 WP3: Scenarios and case studies for future power system. Available for download at www.electrairp.eu 